\title{
EXPERIMENTAL STUDY ON DIFFERENT CHARACTERISTICS OF PLANTAR PRESSURE DISTRIBUTION IN DIFFERENT SPORTS SHOES
}

\author{
Ping WU*
}

Guizhou Medical University, Gui'an 550025, China, wp18185111579@163.com

Received: 07.04.2017

Accepted: 12.05 .2017

https://doi.org/10.24264/Ifj.17.2.5

EXPERIMENTAL STUDY ON DIFFERENT CHARACTERISTICS OF PLANTAR PRESSURE DISTRIBUTION IN DIFFERENT SPORTS SHOES

ABSTRACT. This paper studies the effects of sports shoes in improving people's exercise capacity and preventing sports injuries, and by performing gait $(0.8 \mathrm{~m} / \mathrm{s})$, jogging $(1.5 \mathrm{~m} / \mathrm{s})$ and moderate-speed running $(2.3 \mathrm{~m} / \mathrm{s})$ tests on athletes, discusses the characteristics of plantar pressure distribution on bare foot or in different sports shoes. According to the research results, when athletes are bare foot and wearing sports shoes, the heel region bears the largest pressure in both cases. When bare foot, the plantar pressure on the first toe region is also large, but when in sports shoes, the plantar pressure in this region is significantly reduced. During bare foot gait, plantar pressure is relatively concentrated in toe, forefoot and heel regions; during gait in sports shoes, plantar pressure is evenly distributed. Shoes are designed to allow the arch region to also bear some pressure so that the whole plantar pressure tends to be even. During jogging and gait, the ground reaction forces given by NIKE sports shoes to the 4 plantar regions are small, indicating that NIKE shoes provide better cushioning effects compared with the other two sports shoe brands; ADIDAS shoes provides the poorest cushioning effects - the pressure is high and concentrated in forefoot, arch and heel regions, bringing more harm to the foot arch region. The pressure brought by these 3 brands of sports shoes does not vary much in the toe bone region, but significantly in the arch region.

KEY WORDS: plantar pressure, pressure distribution, sports shoes, pressure intensity, running

STUDIU EXPERIMENTAL PRIVIND CARACTERISTICILE DISTRIBUTIEI PRESIUNII PLANTARE LA PURTAREA DIFERITELOR TIPURI DE PANTOFI SPORT

REZUMAT. Această lucrare studiază efectele încălţămintei sportive asupra îmbunătăţirii capacităţii persoanelor de a face sport şi asupra prevenirii leziunilor cauzate de sport. În urma efectuării unor teste de mers $(0,8 \mathrm{~m} / \mathrm{s})$, jogging $(1,5 \mathrm{~m} / \mathrm{s})$ şi alergare cu viteză moderată $(2,3$ $\mathrm{m} / \mathrm{s}$ ) se discută caracteristicile distribuției presiunii plantare în timpul exercițiilor cu piciorul gol sau purtând diferite tipuri de pantofi sport. Conform rezultatelor cercetărilor, atât în cazul în care sportivii sunt desculţi, cât şi atunci când poartă pantofi sport, regiunea călcâiului suportă cea mai mare presiune. În cazul mersului desculţ, presiunea plantară în zona degetului mare este de asemenea mare, însă la purtarea pantofilor sport, presiunea plantară în această regiune este semnificativ redusă. În timpul mersului desculț, presiunea plantară este relativ concentrată în regiunile degetelor, antepiciorului şi călcâiului; în timpul mersului cu pantofi sport, presiunea plantară este uniform distribuită. Pantofii sunt proiectaţi pentru a permite şi bolţii piciorului să suporte o anumită presiune, astfel încât întreaga presiune plantară să fie distribuită uniform. În timpul jogging-ului şi al mersului, forţele de reacţiune ale solului la purtarea pantofilor sport NIKE în cele 4 regiuni plantare sunt mici, ceea ce indică faptul că pantofii NIKE oferă amortizare mai bună comparativ cu celelalte două mărci de pantofi sport; pantofii ADIDAS oferă cea mai slabă amortizare - presiunea este ridicată și concentrată în regiunile antepiciorului, bolții și călcâiului, dăunând mai mult regiunii bolţii piciorului. Presiunea la utilizarea celor 3 branduri de încălţăminte sport nu variază mult în regiunea osoasă a piciorului, însă este semnificativă în regiunea bolţii piciorului.

CUVINTE-CHEIE: presiune plantară, distribuţia presiunii, pantofi sport, intensitatea presiunii, alergare

ETUDE EXPÉRIMENTALE SUR LES CARACTÉRISTIQUES DE RÉPARTITION DE LA PRESSION PLANTAIRE EN PORTANT DE DIFFÉRENTS TYPES DE CHAUSSURES DE SPORT

RÉSUMÉ. Cet article étudie les effets des chaussures de sport sur le renforcement de la capacité des individus à faire du sport et la prévention des blessures sportives. A la suite des testes de marche $(0,8 \mathrm{~m} / \mathrm{s})$, de jogging $(1,5 \mathrm{~m} / \mathrm{s})$ et de course à une vitesse modérée $(2,3 \mathrm{~m} / \mathrm{s})$ on a discuté les caractéristiques de répartition de la pression plantaire au cours de l'exercice avec les pieds nus ou avec de différents types de chaussures. Selon les résultats de la recherche, n'importe si les athlètes sont pieds nus ou portent des chaussures, la région du talon porte la plus grande pression. Dans le cas de la marche, la pression plantaire aux pieds nus dans la région du grand orteil est aussi grande, mais aux chaussures de sport, la pression plantaire dans cette région est considérablement réduite. Pendant la marche aux pieds nus la pression plantaire est relativement concentrée dans les régions des orteils, de l'avant-pied et du talon; pendant la marche en portant des chaussures de sport, la pression plantaire est uniformément répartie. Les chaussures sont conçues pour permettre à la voûte du pied de porter une certaine pression, de sorte que toute la pression plantaire peut être répartie uniformément. Pendant le jogging et la marche, les forces de réaction au sol en portant des chaussures de sport Nike dans les 4 régions plantaires sont baisses, ce qui indique que les chaussures NIKE offrent un mieux amortissement par rapport aux deux autres marques de chaussures; ADIDAS offre un amortissement plus faible - la pression est élevée et concentrée dans l'avant-pied, la voûte et le talon, endommageant de plus la région de la voûte plantaire. La pression en utilisant les 3 marques de chaussures de sport ne varie pas beaucoup dans la région de l'os du pied, mais elle est considérable dans la région de la voûte plantaire.

MOTS CLÉS: pression plantaire, répartition de la pression, chaussures de sport, intensité de la pression, course

\section{INTRODUCTION}

Walking and running are the most common ways to travel in people's daily life. Whether during normal walking or vigorous exercise, human foot withstands great impacts. Long-time walking would bring great harm to the plantar arch. Suitable sports shoes can effectively reduce the impacts of exercise on human foot, but unsuitable ones would cause a series of diseases like plantar fasciitis, foot bone spur and foot injuries [1-2].

Plantar pressure is the pressure or pressure intensity that human foot withstands during all kinds of exercises. Plantar pressure can 
be classified into static and dynamic pressure. Plantar pressure tests include peak plantar pressure and pressure intensity, average pressure and pressure intensity, and foot touchdown speed and pressure change rates under different motions [3-4]. Different ages, sexes and exercise forms will affect plantar pressure distribution. So far, many scholars have studied how to design sports shoes to improve their cushioning and health care effects. Nawata et al. analyzed the plantar pressure of 70 students during exercise [5]; Sacco et al. analyzed the effects of different types of shoes on the leg muscles and plantar pressure [4]; Mika et al. studied the influence of high heels on the spines and plantar arch of women during gait [6]; Nagel and Van et al. studied how to modify the structure of shoes to reduce the pressure in forefoot [7-8]; De et al. studied the changes in plantar pressure during running on bare foot and in shoes [9]; Henning et al. studied the difference in plantar pressure in different kinds of sports shoes [10]. At the same time, some scholars also designed health- care shoes that could help people lose weight, correct posture, reduce injuries during gait and lower plantar loads [11-17].

This paper studies the effects of sports shoes in improving people's exercise capacity and preventing sports injuries, and by performing gait $(0.8 \mathrm{~m} / \mathrm{s})$, jogging $(1.5 \mathrm{~m} / \mathrm{s})$ and moderate-speed running $(2.3 \mathrm{~m} / \mathrm{s})$ tests on athletes, discusses the characteristics of plantar pressure distribution on bare foot or in different sports shoes. Research conclusions can serve as scientific reference for people during selection of sports shoes.

\section{RESEARCH SUBJECTS AND METHODS}

\section{Research Subjects}

The test subjects are 20 male athletes from an institute of physical education. All these test subjects are healthy and have suffered no structural damage in their lower limbs and feet in the recent year. The basic information on these test subjects are listed in Table 1.

Table 1: Basic information on research subjects

\begin{tabular}{cccccc}
\hline Age/years & Height/cm & Body weight/kg & Foot length/cm & Foot breadth/cm & $\begin{array}{c}\text { Foot arch height/ } \\
\mathrm{cm}\end{array}$ \\
\hline $20 \pm 1.95$ & $180 \pm 4.82$ & $76.28 \pm 5.39$ & $25.79 \pm 0.77$ & $10.11 \pm 0.32$ & $5.01 \pm 0.85$ \\
\hline
\end{tabular}

\section{Test Contents}

Test instruments: 2 plantar pressure test plates; 2 cameras; a set of synchronous lamps and synchronizing system; 2 pieces of processing equipment.

Test on the effects of shoes on plantar pressure: the 20 athletes were divided into 2 groups, with one group wearing sports shoes and the other bare foot when running. We collected the data about the characteristics of plantar pressure in these two groups.

Plantar pressure test in different sports shoes: basketball shoes of different brands but with the same sole thickness and all having cushioning effects should be selected. In this test, we selected Lining (LN), ADIDAS and NIKE basketball shoes. Persons to be tested were arranged to walk $(0.8 \mathrm{~m} / \mathrm{s})$, jog $(1.5 \mathrm{~m} / \mathrm{s})$ and run at a moderate speed $(2.3 \mathrm{~m} / \mathrm{s})$ wearing different brands of sports shoes.
Test indices mainly include the peak pressure, plantar contact area and plantar pressure distribution in different parts of the plantar arch. By using the pressure test and analysis software, we exported the data of the different tests mentioned above and used the SPSS software to do statistics.

\section{TEST RESULTS AND ANALYSIS}

\section{Plantar Pressure Distributions on Bare Foot and in Sports Shoes}

Figures 1 and 2 show the pressure distribution in different regions of the plantar arch when athletes are walking on bare foot and wearing sports shoes. From the figures, it can be seen that whether athletes wear shoes or not, the pressure on the heel is the greatest. During gait on bare foot, the maximum pressure in the heel region is up to $622 \mathrm{~N}$, and during gait in sports shoes, the maximum plantar pressure 
EXPERIMENTAL STUDY ON DIFFERENT CHARACTERISTICS

OF PLANTAR PRESSURE DISTRIBUTION IN DIFFERENT SPORTS SHOES

is $501 \mathrm{~N}$, which also appears in the heel region. In the bare foot case, the plantar pressure in the first toe region is also great, the maximum value of which can be up to $537 \mathrm{~N}$. In the sport shoes case, the plantar pressure in this region is significantly reduced, of which the maximum value is only $313 \mathrm{~N}$. This indicates that sports shoes can well protect and cushion the plantar arch. It can also be seen from the figure that, in the bare foot case, plantar pressure is relatively concentrated in toe, forefoot and heel regions; in the sports shoes case, plantar pressure is evenly distributed. Shoes are designed to allow the arch region to also bear some pressure so that the whole plantar pressure tends to be even. Therefore, wearing sports shoes while doing exercise can effectively protect the plantar arch.

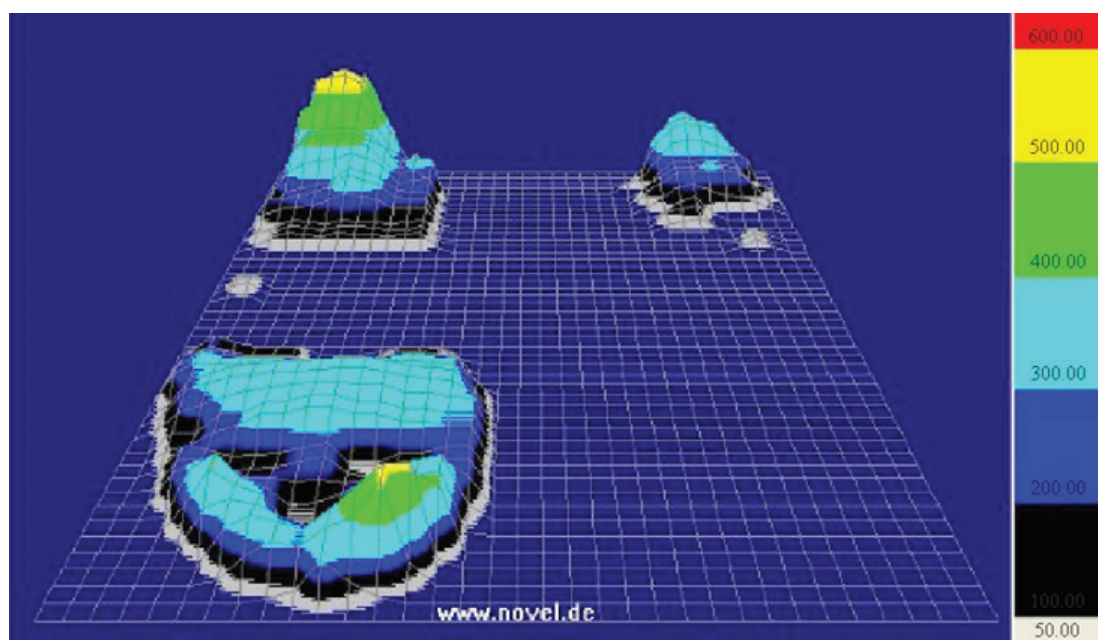

Figure 1. Peak plantar pressure characteristics of bare foot gait

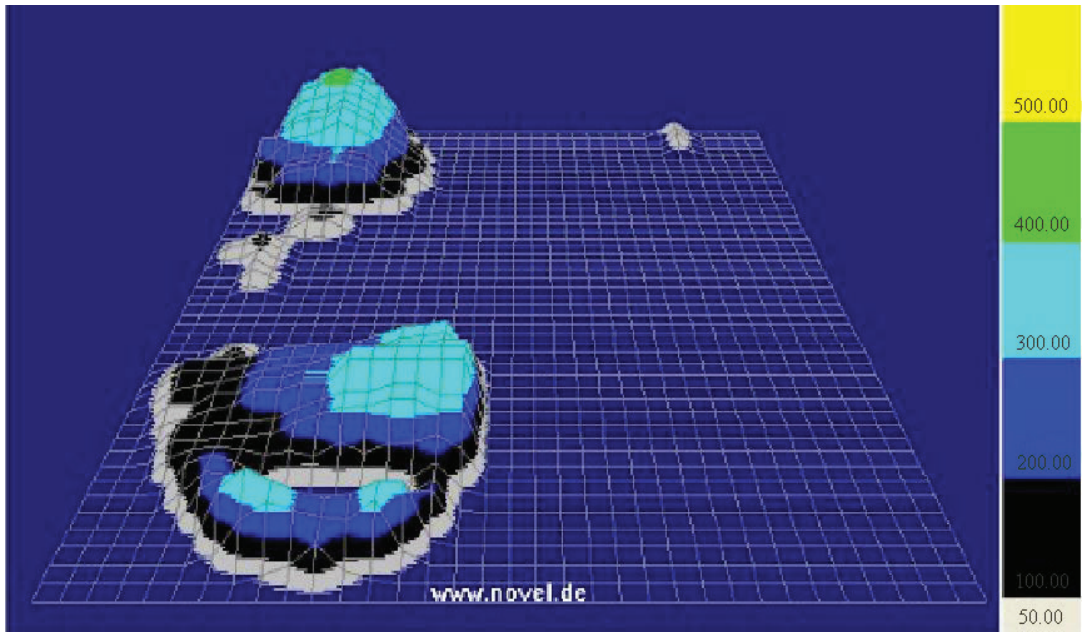

Figure 2. Peak plantar pressure characteristics of wearing sports shoes

\section{Characteristics of Plantar Pressure Distribution in Different Sports Shoes}

Based on the above analysis, we can see that exercising bare foot will cause great load onto the feet, which is not healthy to the human body, while wearing suitable sports shoes in our daily life can effectively mitigate soft tissue injuries in human foot. Therefore, this section studies the characteristics of plantar pressure distribution when athletes are wearing different kinds of sports shoes and analyzes which sport shoes provide better protection for athletes' feet.

In this paper, we divide the plantar arch into 4 regions - toe bone, forefoot, arch and heel, and number them as 1-4 respectively, as shown in Figure 3. 
In this test, we used ADIDAS, LN and NIKE sports shoes. We divide 20 persons into 3 groups, with 7 in Group 1, wearing ADIDAS shoes; 7 in Group 2, wearing LN; and 6 in Group 3 , wearing NIKE. According to the test results of athletes running at different speeds, we obtain the mechanical parameters of different sports shoes, as shown in Table 2, where force MPP represents the maximum reaction force from the ground; peak pressure MPP stands for the peak plantar pressure; mean pressure MVP stands for the mean plantar pressure; and force-time integral means the force-time integral value.

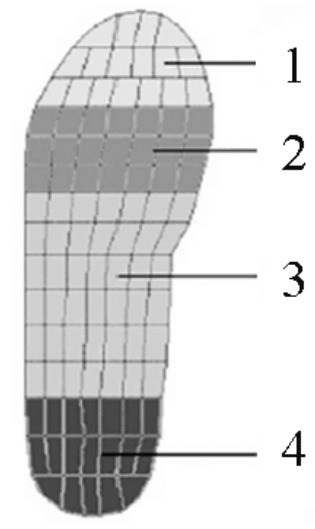

Figure 3. Regional Division of plantar pressure

Table 2: Plantar pressure mechanical parameters of different sports shoes

\begin{tabular}{|c|c|c|c|c|c|}
\hline $\begin{array}{l}\text { Velocity } \\
\text { (m/s) }\end{array}$ & Shoe types & Force MPP/N & Peak pressure MPP/kPa & $\begin{array}{l}\text { Mean pressure } \\
\mathrm{MVP} / \mathrm{KPa}\end{array}$ & $\begin{array}{l}\text { Force time integral/ } \\
\qquad \mathrm{N}-\mathrm{S}\end{array}$ \\
\hline & LN & $760.9 \pm 60.3$ & $239.1 \pm 60.4$ & $33.48 \pm 2.79$ & $421.8 \pm 40.7$ \\
\hline \multirow[t]{3}{*}{0.8} & ADIDAS & $850.7 \pm 40.6$ & $260.3 \pm 55.7$ & $37.91 \pm 2.36$ & $461.3 \pm 49.22$ \\
\hline & NIKE & $749.0 \pm 47.7$ & $182.3 \pm 20.8$ & $31.98 \pm 2.47$ & $369.1 \pm 35.8$ \\
\hline & LN & $1302.1 \pm 119.6$ & $253.8 \pm 58.2$ & $38.17 \pm 2.46$ & $324.8 \pm 20.4$ \\
\hline \multirow[t]{3}{*}{1.5} & ADIDAS & $1330.2 \pm 90.3$ & $279.4 \pm 59.9$ & $40.11 \pm 2.52$ & $361.9 \pm 24.6$ \\
\hline & NIKE & $1189.4 \pm 138.6$ & $249.1 \pm 70.0$ & $34.78 \pm 3.15$ & $299.9 \pm 21.3$ \\
\hline & LN & $1388.4 \pm 200.7$ & $287.3 \pm 38.5$ & $40.27 \pm 3.45$ & $283.5 \pm 14.9$ \\
\hline \multirow[t]{2}{*}{2.3} & ADIDAS & $1539.6 \pm 90.2$ & $310.7 \pm 38.6$ & $45.01 \pm 3.68$ & $321.7 \pm 15.3$ \\
\hline & NIKE & $1422.8 \pm 108.8$ & $273.9 \pm 60.1$ & $42.16 \pm 2.36$ & $271.4 \pm 11.5$ \\
\hline
\end{tabular}

From the table we can see that regarding the maximum reaction force from the ground, in the cases where athletes walk $(0.8 \mathrm{~m} / \mathrm{s})$ and jog $(1.5 \mathrm{~m} / \mathrm{s}), \mathrm{NIKE}<\mathrm{LN}<\mathrm{ADIDAS}$; in the case where athletes run at a moderate speed $(2.3 \mathrm{~m} / \mathrm{s})$, $\mathrm{LN}<$ NIKE $<$ ADIDAS. Therefore, during jogging and gait, NIKE sports shoes have the best cushioning effects, followed by LN, and ADIDAS shoes provide the poorest cushioning. During running at a moderate speed, LN shoes are the best. When the running speed is gradually increased, the plantar pressure and plantar contact area are both increased, and the ground reaction force is also gradually increased.

Figure 4 shows the changes in the peak pressure in different plantar regions when athletes are walking in these three different sports shoes. The horizontal coordinates 1-4 represent the toe bone, forefoot, arch and heel regions. From the figure, it can be seen that for athletes wearing ADIDAS shoes, the pressure is high and concentrated in forefoot, arch and heel regions, which brings great harm to the foot arch region and can easily cause plantar fasciitis. LN sports shoes give less pressure to the toe bone and arch regions than ADIDAS, indicating that LN shoes protect the arch region better, but as this type of LN shoes are not equipped with separate cushioning materials in the forefoot region, the ground reaction force to the forefoot region is the greatest. The ground reaction forces given by NIKE sports shoes to the 4 plantar regions are small, indicating that NIKE shoes provide the best protection for plantar arch during gait. 


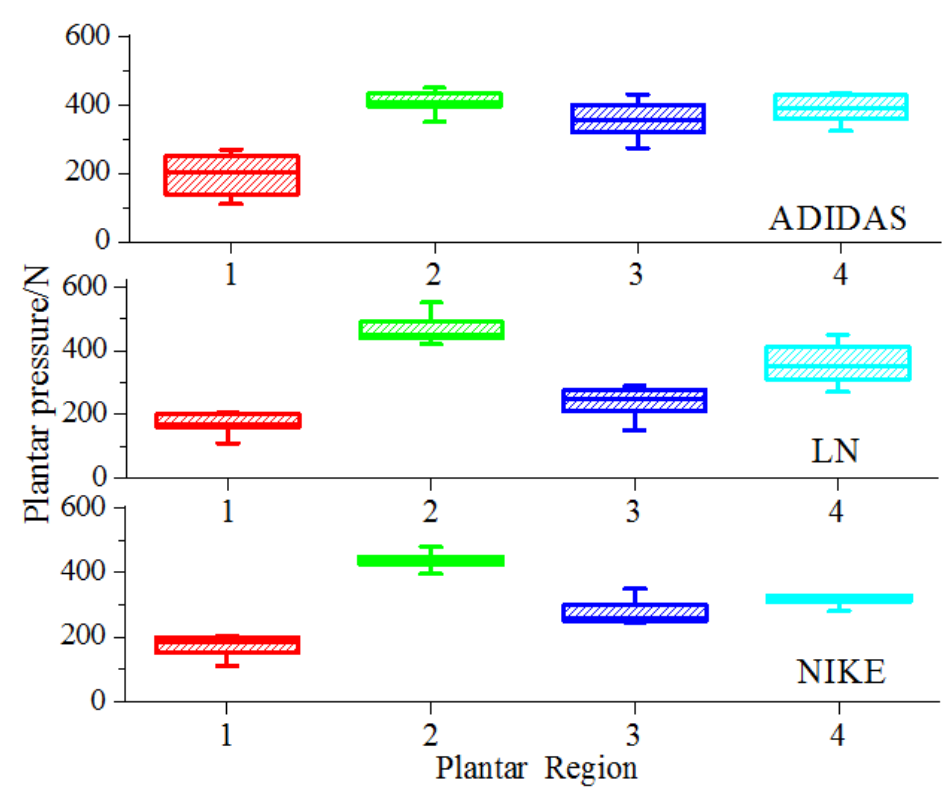

Figure 4. Plantar pressure of different region in different sports shoes

At the same moving speed, the foot withstands the same ground reaction force, but as the shoes are different, different elastic effects will occur when the foot acts on the sole. From the peak plantar pressure listed in Table 2, it can be seen that regarding the peak plantar pressure given by the three kinds of sports shoes in the three exercises is NIKE<LN<ADIDAS; in other words, NIKE sports shoes give the lowest peak plantar pressure, indicating that they provide good cushioning and protection for feet. Figure 5 shows the peak pressure in the
4 plantar regions when athletes are walking in three different kinds of sports shoes. Based on Table 2 and Figure 5, it can be concluded that the pressure in the forefoot given by the three kinds of shoes is: NIKE $<A D I D A S<L N$; and that the pressure in the heel region is: NIKE $\angle L N<A D I D A S$. From the analysis in the previous section, we can see that the forefoot and the heel are the two regions bearing the largest pressure. Compared with NIKE sports shoes, LN and ADIDAS sports shoes do not provide very stable foot protection and can easily cause sport injuries.

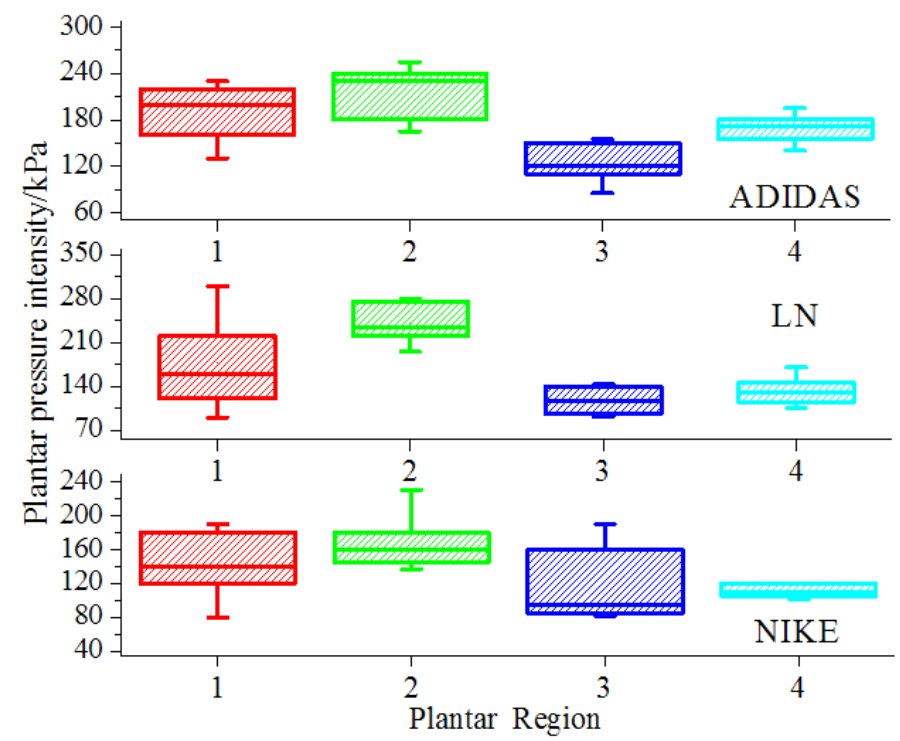

Figure 5. Plantar pressure intensities of different regions in different sports shoes 
The mean plantar pressure intensity reflects the average value of the plantar pressure intensity during a certain period. The greater the mean plantar pressure intensity is, the more unsuitable the sports shoes will be in long-time running. From the statistics given in Table 2, it can be seen that during gait and jogging, the mean plantar pressure intensity of sports shoes is NIKE $<\mathrm{LN}<$ ADIDAS; and that the mean pressure intensity during the moderate-speed running is
$\mathrm{LN}<$ NIKE $<$ ADIDAS. From Figure 6, for ADIDAS sports shoes, the toe bone, arch and heel regions bear the largest mean pressure intensity, while for LN sports shoes, the forefoot region bears the greatest mean pressure intensity. Variance analysis results show that there are significant differences between ADIDAS and NIKE. Therefore, during the three exercises, ADIDAS sports shoes are the least comfortable and NIKE ones are the best.

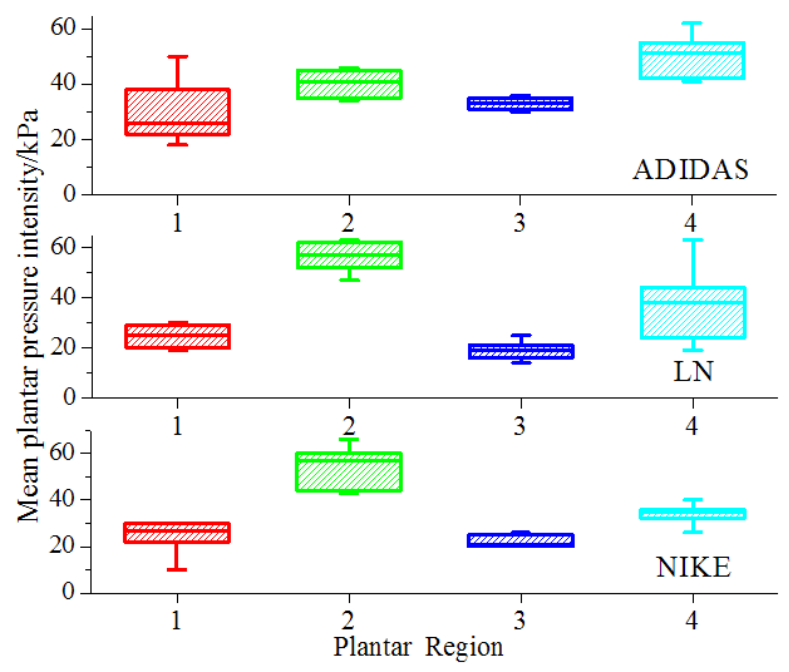

Figure 6. Mean plantar pressure intensities of different regions in different sports shoes

The force-time integral stands for the accumulated effects of pressure in each plantar region after athletes exercise for a certain period. When the speed increases, the average gait cycle is reduced. The plantar pressure is inversely proportional to the force-time integral. From Table 2, it can be seen that the force-time integrals for the three sports shoes are NIKE $<\mathrm{LN}<$
ADIDAS. Figures 7 and 8 show the force-time curves of athletes walking and jogging in three different sports shoes. According to these figures, the overall integral performance of ADIDAS is the worst, that of LN is medium and that of NIKE is the best. As the NIKE sports shoes selected in the test are equipped with full-length air cushions, they are the best in terms of comfortableness.

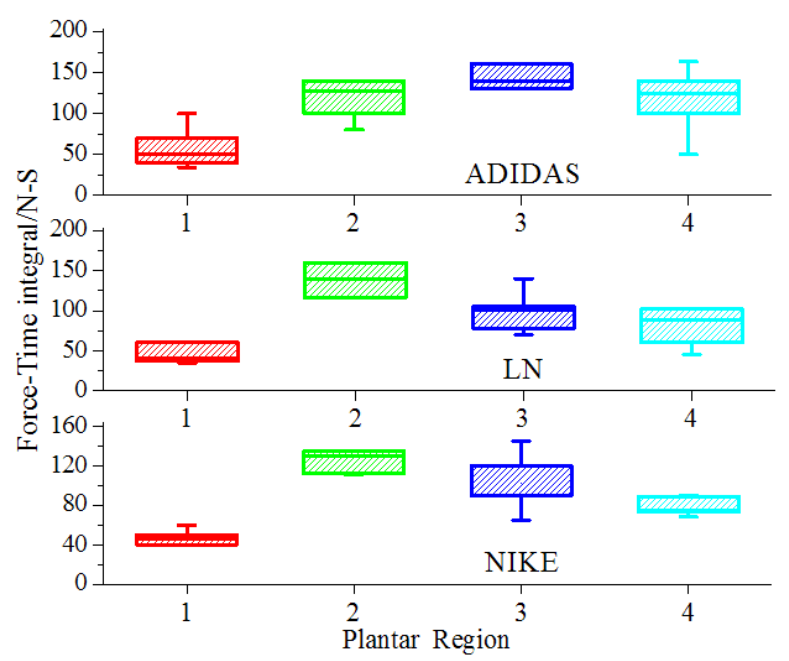

Figure 7. Force-time integrals for different sports shoes during gait at a velocity of $0.8 \mathrm{~m} / \mathrm{s}$ 


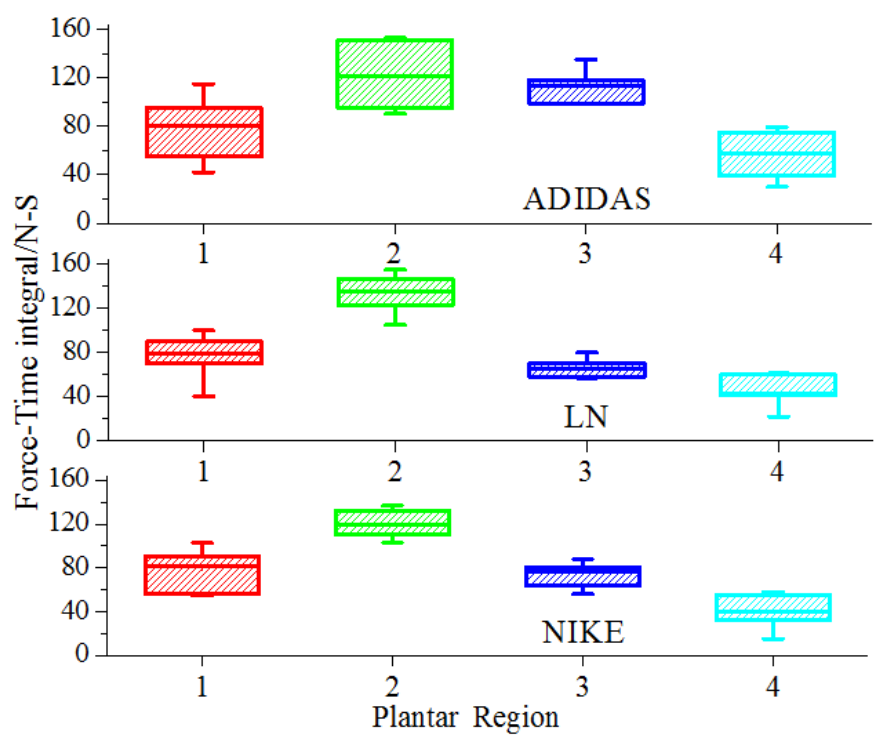

Figure 8. Force-time integrals for different sports shoes during running at a velocity of $1.5 \mathrm{~m} / \mathrm{s}$

We select one athlete and let him jog at a speed of $1.5 \mathrm{~m} / \mathrm{s}$ wearing NIKE shoes and ADIDAS shoes, respectively. The ratios between the peak pressure of different plantar regions and the weight of the athlete are shown in Table 3. From the table we can see that, when the athlete is wearing the NIKE shoes, the ratios between the peak pressure in the toe tone region and the arch region and the weight of the athlete are higher than those in the ADIDAS case by $12.95 \%$ and $7.35 \%$ respectively; the ratios between the peak pressure in the forefoot region and the heel region and the weight of the athlete are lower than those in the ADIDAS case by 14.62 and $26.22 \%$.

Table 3: Ratio between plantar pressure and body weight

\begin{tabular}{ccccc}
\hline Plantar region & ADIDAS & NIKE & Difference & Change percentage / \% \\
\hline 1 & 0.121 & 0.139 & 0.018 & 12.95 \\
2 & 0.345 & 0.301 & -0.044 & -14.62 \\
3 & 0.416 & 0.449 & 0.033 & 7.35 \\
4 & 0.621 & 0.492 & -0.129 & -26.22 \\
\hline
\end{tabular}

Similarly, the statistics of plantar pressuretime integral when the athlete wears NIKE and ADIDAS shoes are shown in Table 4. From the table we can see that, when the athlete is wearing the NIKE shoes, the ratios between the peak pressure in the toe tone region and the arch region and the weight of the athlete are higher than those in the ADIDAS case by $17.61 \%$ and $18.27 \%$ respectively; the ratios between the peak pressure in the forefoot region and the heel region and the weight of the athlete are lower than those in the ADIDAS case by $9.42 \%$ and $20.62 \%$.

Table 4: Pressure-Time integral for different sports shoes during running at a velocity of $1.5 \mathrm{~m} / \mathrm{s}$

\begin{tabular}{ccccc}
\hline Plantar region & ADIDAS & NIKE & Difference & Change percentage/\% \\
\hline 1 & 50.48 & 61.27 & 10.79 & 17.61 \\
2 & 45.29 & 41.39 & -3.9 & -9.42 \\
3 & 40.98 & 50.14 & 9.16 & 18.27 \\
4 & 38.79 & 32.16 & -6.63 & -20.62 \\
\hline
\end{tabular}


Therefore, from Tables 3 and 4, we can see that compared with ADIDAS, when the athlete wears NIKE shoes, the plantar pressure shifts obviously - the peak pressure in the forefoot and heel regions is allocated to the toe bone and arch regions so that the plantar pressure is more evenly distributed and the foot can be better protected.

\section{CONCLUSIONS}

This paper studies the effects of sports shoes in improving people's exercise capacity and preventing sports injuries, and by performing gait $(0.8 \mathrm{~m} / \mathrm{s})$, jogging $(1.5 \mathrm{~m} / \mathrm{s})$ and moderate-speed running $(2.3 \mathrm{~m} / \mathrm{s})$ tests on athletes, discusses the characteristics of plantar pressure distribution on bare foot or in different sports shoes. The research conclusions are as follows:

(1) When athletes are bare foot and wearing sports shoes, the heel region bears the largest pressure in both cases. When bare foot, the plantar pressure on the first toe region is also large, but when in sports shoes, the plantar pressure in this region is significantly reduced, indicating that sports shoes can protect and cushion the heel well. During bare foot gait, plantar pressure is relatively concentrated in toe, forefoot and heel regions; during gait in sports shoes, plantar pressure is evenly distributed. Shoes are designed to allow the arch region to also bear some pressure so that the whole plantar pressure tends to be even.

(2) Forefoot and heel are the two regions bearing the greatest pressure in the plantar arch. During jogging and gait, the ground reaction forces given by NIKE sports shoes to the 4 plantar regions are small, indicating that NIKE shoes provide better cushioning effects compared with the other two sports shoe brands; ADIDAS shoes provides the poorest cushioning effects - the pressure is high and concentrated in forefoot, arch and heel regions, bringing more harm to the foot arch region.

(3) The pressure brought by these 3 brands of sports shoes does not vary much in the toe bone region, but significantly in the arch region. Compared with NIKE sports shoes, LN and ADIDAS sports shoes do not provide very stable foot protection and can easily cause sport injuries. NIKE sports shoes provide the best protection for plantar arch during gait.

\section{REFERENCES}

1. Burnfield, J.M., Few, C.D., Mohamed, O.S., Perry, J., The influence of walking speed and footwear on plantar pressures in older adults, Clin Biomech, 2004, 19, 1, 78-84, https://doi. org/10.1016/j.clinbiomech.2003.09.007.

2. Morag, E., Cavanagh, P.R., Structural and functional predictors of regional peak pressures under the foot during walking, $J$ Biomech, 1999, 32, 4, 359-370, https://doi. org/10.1016/S0021-9290(98)00188-2.

3. Hopkins, J.T., Coglianese, M., Glasgow, P., Reese, S., Seeley, M.K., Alterations in evertor/ invertor muscle activation and center of pressure trajectory in participants with functional ankle instability, J Electromyogr Kinesiol, 2012, 22, 2, 280-285, https://doi. org/10.1016/j.jelekin.2011.11.012.

4. Dowling, A.M., Steele, J.R., Baur L.A., Does obesity influence foot structure and plantar pressure patterns in prepubescent children? Int J Obes Relat Metab, 2001, 25, 6, 845-852, https://doi.org/10.1038/sj.ijo.0801598.

5. Morrison, K.E., Hudson, D.J., Davis, I.S., Richards, J. G., Royer, T. D., \& Dierks, T. A., Kaminski, T.W., Plantar pressure during running in subjects with chronic ankle instability, Foot Ankle Int, 2010, 31, 11, 994-1000, https://doi. org/10.3113/FAl.2010.0994.

6. Nawata, K., Nishihara, S., Hayashi, I., Teshima, R., Plantar pressure distribution during gait in athletes with functional instability of the ankle joint: preliminary report, J Orthop Sci, 2005, 10, 3, 298-301, https://doi.org/10.1007/ s00776-005-0898-4.

7. Nagel, A., Fernholz, F., Kibele, C., Rosenbaum, D., Long distance running increases plantar pressures beneath the metatarsal heads: A barefoot walking investigation of 200 marathon runners, Gait Posture, 2008, 27, 1, 152-155, https://doi.org/10.1016/j. gaitpost.2006.12.012.

8. Van,S.C.,Ulbrecht,J.S., Becker, M.B., Cavanagh, P.R., Design criteria for rigid rocker shoes, Foot Ankle Int, 2000, 21, 10, 833-844, https://doi. org/10.1177/107110070002101007.

9. Wit, B.D., Clercq, D.D., Aerts, P., Biomechanical analysis of the stance phase during barefoot and shod running, J Biomech, 2000, 33, 3, 
269-278, https://doi.org/10.1016/S00219290(99)00192-X.

10. Hennig, E.M., Milani, T.L., In-shoe pressure distribution for running in various types of footwear, J Appl Biomech, 1995, 11, 3, 299310, https://doi.org/10.1123/jab.11.3.299.

11. Harnagea, F., Harnagea, M.C., Diversification of Footwear through Development of the Shoe Uppers, Leather and Footwear Journal, 2010, 10, 3, 25-38.

12.Brown, D., Wertsch. J.J., Harris, G.F., Klein, J., Janisse, D., Effect of rocker soles on plantar pressures, Arch Phys Med Rehabil, 2004, 85, 1, 81-86, https://doi.org/10.1016/S00039993(03)00374-5.

13.Driscu, M., Pastina, M., CRISPIN Dynamics 3D New Solution for Shoemakers, Creating and Modifying the Shoe Last, Leather and Footwear Journal, 2011, 11, 2, 109-120.

14.Kavros, S.J., Van-Straaten, M.G., ColemanWood K.A., Kaufman, K.R., Forefoot plantar pressure reduction of off-the-shelf rocker bottom provisional footwear, Clin Biomech, 2011, 26, 7, 778-782, https://doi. org/10.1016/j.clinbiomech.2011.03.009.
15.Praet, S.F., Louwerens J.W., The influence of shoe design on plantar pressures in neuropathic feet, Diabetes Care, 2003, 26, 2, 441-445, https://doi.org/10.2337/ diacare.26.2.441.

16.Boyer, K.A., Andriacchi, T.P., Changes in running kinematics and kinetics in response to a rockered shoe intervention, Clin Biomech, 2009, 24, 10, 872-876, https://doi. org/10.1016/j.clinbiomech.2009.08.003.

17.Mihai, A., Costea, M., Bilalis, N., Grancaric, A.M., Costa, E., Marzo, R., Azevedo, C., Carvalho, C.V.D., TIED SHOE, a Virtual Community of Practice for the Footwear Industry, Leather and Footwear Journal, 2013, 13, 4, 321-344, https://doi.org/10.24264/ Ifj.13.4.5.

(C) 2017 by the author(s). Published by INCDTPICPI, Bucharest, RO. This is an open access article distributed under the terms and conditions of the Creative Commons Attribution license (http://creativecommons.org/licenses/by/4.0/). 